\title{
Okul Öncesi Dönemdeki Çocukların Duygu Düzenleme Becerileri İle Mizaç Özellikleri ve Ebeveyn Tutumları Arasındaki İlişkinin İncelenmesi ${ }^{1}$
}

\section{Investigation of Relationship Between Emotion Regulation Skills and Temperament Characteristics and Parental Attitudes of Preschool Children}

\author{
Özlem Gözün Kahraman ${ }^{1 *}$, Elif Gökşen ${ }^{1}$ \\ ${ }^{1}$ Doç.Dr, Karabük Üniversitesi, Sağlık Bilimleri Fakültesi, Çocuk Gelişimi Bölümü, okahraman@karabuk.edu.tr, \\ https://orcid.org/ 0000-0003-2767-0592 *Sorumlu Yazar \\ ${ }^{2}$ Bilim Uzmanı, M.E.B.Adana Seyhan Zübeyde Hanım Anaokulu, elif198612@gmail.com, https://orcid.org/ \\ 0000-0002-0387-3646
}

Geliş tarihi/Received : 31.12.2020 Kabul tarihi/Accepted: 22.06.2021 Yayın tarihi/Published: 30.06.2021

\begin{abstract}
ÖZET
Bu çalışmanın amacı okul öncesi dönem çocuklarının duygu düzenleme becerileri ile mizaç ve ebeveyn tutumları arasındaki ilişkinin incelenmesidir. Araştırma ilişsisel tarama yöntemiyle yapılmıştır. Araştırma, 2016-2017 yılında Adana İl Milli Eğitim Müdürlüğü'ne bağlı anasınıfları ve anaokullarında yürütülmüş̧ür. Araştırmanın çalışma grubunu 4-6 yaş grubu 400 çocuk oluşturmaktadır. Araştırmada veri toplama aracı olarak; "ÇKMÖ", "ETÖ", "DDÖ" ve "Demografik Bilgi Formu" kullanılmıştır. Araştırma sonucunda; duygu düzenleme ve ebeveyn tutumları arasında ilişki incelendiğinde duygu düzenleme ve sadece demokratik ebeveyn tutumu arasında pozitif yönlü ilişki olduğu tespit edilmiştir. Bulunan bu ilişkiye göre çocukların duygu düzenleme becerileri arttıkça demokratik ebeveyn tutumları da artmaktadır. DDÖ'nün değiş̧enlik/olumsuzluk alt boyutu ile ÇKMÖ'nün tepkisellik alt boyutu arasında pozitif, ÇKMÖ'nün sebatkarlık alt boyutu ile negatif yönlü ilişki olduğu görülmüştür. Sebatkarlık ve tepkisellik mizaç özelliğinin DDÖ'nün değişkenlik/olumsuzluk boyutu ile arasında anlamlı ilişki olduğu belirlenmiştir. Bu sonuçlar çocukların duygu düzenleme becerilerinin ebeveyn tutumları ve çocuğun mizacından etkilendiğini göstermektedir.
\end{abstract}

Anahtar Kelimeler: Duygu düzenleme, ebeveyn tutumları, mizaç, okul öncesi dönem

\begin{abstract}
In this study, it was aimed to investigate the relationship between emotion regulation skills and temperament and parental attitudes of preschool children. The study was conducted by relational screening method. The research was carried out in 2016-2017 in kindergartens of Adana Province National Education. The study group of the research consists of 400 children with in 4-6 age group.. As a data collection tool; "Short Temperament Scale for Children" "Parental Attitude Scale", "Emotion Regulation Scale" and "Demographic Information Form" were used. As a result of the research; When the relationship between emotion regulation and parental attitudes were examined, it was found that there was a positive relationship between emotion regulation and only democratic parental attitudes. According to this relationship, democratic parental attitudes are increasing as children's emotion regulation skills increase. It was observed that there was a negative relationship between the variability / negativity sub-dimension of regressive ability and reactive temperament characteristic with positive, steadfast temperament feature. It was determined that the feature of regressive and reactive temperament was a significant predictor of variability and negativity. These results show that children's emotion regulation skills are affected by parental attitudes and the child's temperament.
\end{abstract}

Keywords: Emotion regulation, parental attitudes, pre-school period, temperament

\footnotetext{
${ }^{1}$ Bu çalışma birinci yazarın danışmanlığındaki ikinci yazarın yüksek lisans tezinden üretilmiştir. Bu tez, Karabük Üniversitesi Bilimsel Araştırma Projeleri Komisyonu Başkanlığı tarafından KBÜBAP-17-YL-190 numaralı proje ile desteklenmiştir.
} 


\section{Gİiș}

Duygu, insan yaşamına canlılık katan ve insan yaşamını zenginleştiren, insan deneyiminin en önemli özelliklerinden biri olarak tanımlanmaktadır (Shahbaa, Alvani, Zahedi ve Memarzadeh, 2014). Duygular insanları bir araya getirir ve insanın hayatta kalma mücadelesinde kritik bir öneme sahiptir (Santrock, 2015; Southam-Gerow, 2014). Normal gelişim gösteren tüm bireylerin aynı temel duygulara sahip oldukları bilinir. Duygular bireyin yaşama uyum sağlamasına yardımcı olur. Her insan belli bir durum karşısında tepksini farklı tarzda gösterir. Örneğin, ağlamak bazen üzüntü bazen sevinçle ilişkili olabilir (San-Bayhan ve Artan, 2011). Duygular araştırmacılar tarafından farklı şekillerde sınıflandırılmıştır. Genellikle olumlu ve olumsuz olarak ikiye ayrılan duyguları hoşa giden ve hoşa gitmeyen duygular olarak da sınıflandırmak mümkündür. Olumlu duygular; coşku, sevinç ve sevgiyi içerirken, olumsuz duygular ise kaygı, öfke, suçluluk ve üzüntüyü içerir (Santrock, 2015). Mutluluk, ilgi, şaşırma (hayret), korku, öfke, sevgi, üzüntü ve tiksinme gibi duygular insanlarda evrenseldir (Berk, 2013).

Duygular yanlış türde, yoğunlukta ve sürede olduğunda, ya da düzenlenmediğinde günlük yaşamı olumsuz yönde etkiler. Duygu düzenleme; olumlu veya olumsuz duygularla başa çıkmak için, duygusal tepkilerin süresini ve yoğunluğunu bireyin hedeflerine ulaşmasını sağlayacak bir düzeye ayarlamada kullandığı stratejiler olarak adlandırılır (Gross ve Thompson, 2007). Duygu düzenleme, yeni bir duygusal tepkinin başlatılmasını ya da devam eden duygusal tepkilerin değişmesini içerir (Ochsner ve Gross, 2005). Duygu düzenleyici süreçler otomatik veya kontrollü, bilinçli ya da bilinçsiz olabildiği gibi duygu düzenlemeyi de etkileyebilir. Çünkü duygular çok bileşenli süreçlerdir (Gross, 1998). Duygu düzenleme becerilerinin kazanılması, önemli bir gelişimsel görevdir. Başarılı bir gelişim sürecinden geçmesi beklenilen duygu düzenleme becerileri bireyin hayatında kritik bir öneme sahiptir (Cole, Martin ve Dennis, 2004). Gelişimsel dönemlere göre çocukların duygu düzenleme becerilerinde gösterdikleri yeterlikler de değişiklik gösterir. Okul öncesi dönemde çocuklar yetişkinlerden destek alarak duygu düzenleme tekniklerini kullanmaya eğilimlidirler. Ergenlik döneminde ise bilişsel becerilerinin ve problem çözme yeterliliklerinin gelişimiyle kendi duygu düzenleme stratejilerini belirleyip uygularlar (Essau vd., 2017).

Duygu düzenlemenin gelişimi ise, bebeğin doğduğu andan itibaren edinilen çeşitli becerilerle zaman içinde kademeli olarak gelişim gösterir (Dodge ve Garber, 1991). Bebekler, ilk aylarda duygusal durumlarını düzenlemek için kısıtlı bir yeteneğe sahiptirler. Bebekler ilk yıllarda duygusal tepkilerin süresi ve şiddetini engelleme ya da azaltma becerisini kademeli olarak geliştirirler (Rothbart, Ziaie ve O'Boyle, 1992; Santrock, 2015). Yaşamın ilk aylarında başını çevirme, emme, ağlama gibi duygu düzenleme davranışları mevcuttur (Thompson, 1994). Bebek yaşına yaklaştıkça bilişsel gelişimin ilerlemesine paralel olarak duygu düzenleme süreçlerinde aktif olmaya başlar (Kopp, 1982). Bebek duygusal süreçlerde aktif olmaya başladıkça ise dış dünyaya verdiği tepkilerde amaçlı bir biçimde duygularını yönetmek için stratejiler kullanmaya başlar (Calkins ve Fox, 2002).

Bebeklik dönemindeki anne-çocuk ilişkisinin kalitesi, okul öncesi dönemdeki duygu düzenlemeyi etkiler. $\mathrm{Bu}$ dönemde çocuklar gelişim özelliklerinin gerektirdiği şekilde davranırlar ve bebeğin anneyle kurduğu bağlanmanın sonuçlarını da sonraki gelişim dönemlerine taşırlar (Kelly, Slade ve Grienenberger, 2005). İki yaşından sonra çocuklar dil gelişimiyle birlikte sık sık duygularını ifade eder ve duygularını aktif olarak gözetim altında tutmaya çalışır (Berk, 2013). Duyguları düzenleme becerisi okul öncesi dönemde sosyal çevreden fazlasıyla etkilenir. Çocuklar çevrelerindeki kişilerin duygularını başarıyla yönettiğini gözlemlediğinde, duygu düzenlemenin olabileceğini öğrenirler (Campos, Campos ve Barrett, 1989). Çocuklar sosyal çevresindeki bireylerin duygularının kontrol dışında olduğunu 
gözlemler ve tecrübe ederse, duygu düzenlemede problemler yaşayabilirler (Reider ve Cicchetti, 1989). Bu dönemde yaşanan duygu düzenleme konusundaki eksiklikler ve başarısızlıklar, çocuğun çevresiyle ilişkilerinde sorun yaşamasına ve okula uyum sağlayamamasına sebep olur. Bu sebeple okul öncesi dönem, duygu düzenleme becerilerinin edinilmesinde kritik bir dönem olarak değerlendirilir (Calkins ve Hill, 2007).

Duygu düzenlemenin amacı, "olumsuz" duyguları ortadan kaldırmak değil, çevreye karşı olumlu tepkiler üretmek için duyguları ayarlamaktır. Bir diğer duygu düzenleme amacı, duyguların ortamın sürekli değişen taleplerine uygun tepki vermesini kolaylaştırabilmesi için en uygun düzeyde duygu dinamikleri elde etmektir (Aldao, 2013).

Duygu düzenlemenin gelişimini etkileyen içsel ve disssal unsurlar mevcuttur (Fox ve Calkins, 2003). Ebeveynler hem mizaç, genetik yatkınlık gibi içsel faktörleri hem de bağlanma, ebeveyn tutum ve davranışları gibi dışsal faktörleri etkilediği için duygu düzenleme becerilerinin gelişiminde önemli etkilere sahiptirler (Calkins ve Hill, 2007). Çocukların duygularını düzenleme yeteneği, çocuğun mizacına bağlı olarak değişebilir. Örneğin, mizaç yaklaşımındaki değişiklikler, düzenlemeyi gerektirebilecek farklı duygular üretir. Birçok çalışmada, değişken veya heyecanlı duyguları olan çocukların dışa dönük davranışlar için risk altında olduğu tespit edilmiştir. Öte yandan, aşırı bastırılmış duyguları olan çocukların içselleştirici davranışlar geliştirmesi daha olasıdır (Stifter-Dollar ve Cipriano 2010). Mizaç, kendine özgü bir şekilde bireysel farklılıkların ilk çekirdeğini oluşturur ve davranış eğilimleri, dikkatin sürdürülebilirliği kapasitelerini ifade eder (Rothbart, 2004). Duygusal düzenlemede yer alan becerilerin çoğunun mizaç temelli olduğu düşünülmektedir (Eisenberg, Spinrad ve Eggum, 2010). Çocukların duygularını düzenleme yeteneği, çocuğun mizacına bağlı olarak değişebilir. Mizaçsal yaklaşımdaki değişiklikler, düzenlemeyi gerektirebilecek farklı duygular üretir (Rothbart ve Bates, 2006). Olumsuz duyguların fazla olması, çocuğun kişilerarası etkileşimlerde zorluk çekme olasılığını artırır. Ayrıca çocuğun daha yoğun tepkiler vermesine neden olur. Fox (1989) yüksek seviyede tepkisel olan çocukların, daha az tepkisel olan akranlarına göre duygularını düzenlemek için bakım verenlerin yardımına daha çok ihtiyaç duyduğunu bulmuştur (Akt.Yağmurlu ve Altan, 2010).

Ayrıca bebeklerde ve küçük çocuklarda duygu düzenlemenin gelişimi bakım verenler tarafından önemli düzeyde etkilenir. Ebeveynlerin çocuğunun duygusal ifadesine verdiği yanıtlar ve ilişkilerin güvenli olması erken çocukluk döneminde duygu düzenlemenin gelişimini önemli derecede etkiler (Brownell ve Kopp, 2007). Ebeveynler çocukların duygusal ihtiyaçlarına karşı destekleyici ve 1lımlı yaklaştıklarında çocukların olumsuz durumlarla daha rahat baş ettikleri belirlenmiştir. Fakat çocukların duygusal ihtiyaçlarına yönelik cezalandırıcı ve küçümseyici yaklaşması, çocukların duygu düzenleme becerilerini olumsuz yönde etkilemektedir. Bu anlamda, ebeveyn tutumlarının çocukların duygu düzenleme becerileri üzerinde doğrudan etkisi olabilir. Bu yüzden uygulanan ebeveyn tutumunun dikkatli seçilmesi çok önemlidir (Gross, 2007).

Erken çocukluk döneminde duygu düzenleme ile ilgili yapılan yurt içi ve yurt dışı çalı̧malara bakıldığında, duygu düzenleme becerilerinin yurt dışında çocukluk kanseri (Firoozi, Besharat ve Boogar, 2013), akut lenfoblastik lösemili çocuklar (Firoozi, Besharat ve Tehrani, 2011), oyun (LaFreniere, 2013), risk altındaki çocuklar (Thompson ve Calkins, 1996) ve cinsiyet farklılıkları (Goldstein, 2015) gibi değişkenlerle çalışıldığı görülürken; yurtiçinde duygu düzenleme becerilerinin çocukların sosyal davranışları (Arı ve Yaban, 2016), annenin duygusal sosyalizasyonu (Sille, 2016), ebeveyn tutumları (Yaman, 2018), saldırganlık düzeyleri (Ersan, 2017), çocukluk çağı travmaları (Demirkapı, 2013), akran ilişkileri (Kayhan-Aktürk 2015), annelerin duygu sosyalleştirme davranışları (Seçer, 2016), ebeveynlerin duygusal okuryazarlık düzeyleri (Bozkurt-Yükçü, 2017) ve duygu düzenleme becerilerine yönelik eğitim programının etkililiğinin (Uğur-Ulusoy ve Gözün Kahraman, 2019) incelendiği çalışmalar olduğu 
görülmüştür. Okul öncesi dönemde duygu düzenleme becerilerinin gelişiminin kritik bir öneme sahiptir Okul öncesi dönemde duygu düzenleme becerilerinde görülen yetersizlik, çocuğun sosyal ve okul ilişkilerinde güçlükler yaşamasına neden olabilir. $\mathrm{Bu}$ nedenle bu çalışmada, duygu düzenleme, mizaç ve ebeveyn tutumu arasındaki ilişki incelenmiştir. Bu çalışmanın sonraki çalışmalara rehber olacağı ve alan yazına katkı sağlayacağı düşünülmektedir.

\section{YÖNTEM}

Bu bölümde araştırmanın modeli, araştırmanın evren ve örneklemi, araştırmada kullanılan veri toplama aracı, verilerin toplanması, araştırmanın etik yönü, kapsam ve sınırlılıkları açıklanmıştır.

\section{Araştırmanın Modeli}

$\mathrm{Bu}$ çalışmada ilişkisel tarama yöntemi kullanılmıştır. İlişkisel taramalar, en az iki değişken arasında yapılır ve değişkenlere müdahale edilmez. Bu araştırmalar, değişkenler arasındaki ilişkileri inceler ve ilişkilerin belirlenmesi bireyin varsayımda bulunabilmesini sağlar (Büyüköztürk, K1lıç, Akgün, Karadeniz ve Demirel, 2016; Fraenkel, Wallen ve Hyun 2012).

\section{Çalışma Grubu}

Bu araştırma, 2017-2018 eğitim-öğretim yılında Adana ili Seyhan, Çukurova, Sarıçam, Yüreğir ve İmamoğlu, Kozan ilçelerinde bulunan anaokulları ve ilkokul bünyesinde bulunan anasınıflarında gerçekleştirilmiştir. Araştırmada çalışma grubu uygun/kazara örnekleme yöntemi kullanılarak oluşturulmuştur. Okul öncesi eğitim kurumuna devam eden 219 'u kız, 181'i erkek olmak üzere toplam 400 çocuk çalışma grubunu oluş̧urmuş̧ur. Çalışma grubundaki çocukların \%54.8'i kız, \%45.3'ü erkektir. Çocukların \% 33,5'i (n=134) 4 yaş, \%36'sı (n=144) 5 yaş ve \%30,5'i (n=122) 6 yaştır.

\section{Veri Toplama Araçları}

Araştırmada çocuk ve ailesi hakkındaki kişisel bilgileri toplayabilmek için "Genel Bilgi Formu", çocukların duygu düzenleme becerilerinin belirlenmesi için "Duygu Düzenleme Ölçeği (DDÖ)", çocukların mizaçlarını ölçmek amacıyla "Çocuklar için Kısa Mizaç Ölçeği (ÇKMÖ)" ve anne-babaların çocuk yetiştirme tutumlarını belirlemek için "Ebeveyn Tutum Ölçeği (ETÖ)" kullanılmıştır.

\section{Genel Bilgi Formu}

Araştırmacı tarafindan oluşturulan demografik bilgi formunda; çocuğun yaşı, cinsiyeti, annenin ve babanın yaşı, annenin ve babanın öğrenim durumu ve ailenin aylık geliri sorulmuştur. $\mathrm{Bu}$ form, ebeveynler tarafından doldurulmuştur

\section{Duygu Düzenleme Ölçeği (DDÖ)}

Duygu düzenleme ölçeği (DDÖ) Shields ve Cicchetti tarafından (1997) geliştirilmiştir. Ebeveyn ve öğretmenlere uygulanabilen 24 maddelik ölçek Değişkenlik/Olumsuzluk ve Duygu Düzenleme olarak iki alt ölçekten oluşur. Değişkenlik/Olumsuzluk alt ölçeği; eylem, öfke kontrolü, duygu durum kararsızlığı, tepkisellik ve esnek olmayan maddelerden oluşur. Duygu Düzenleme alt ölçeği ise; empati, uygun pozitif ve negatif duygu görüntüleme, duygusal farkındalık maddelerinden oluşur. Duygu Düzenleme alt ölçeği maddeleri 1'den (Hiçbir zaman/Nadiren), 4'e (Her zaman) kadar derecelendirilmiştir. Değişkenlik/Olumsuzluk alt ölçek maddeleri 2, 6, 8, 10,13,14, 17, 19, 20, 22, 24, 4 (tersten puanlanır), 5 (tersten puanlanır), 9 (tersten puanlanır), 11 (tersten puanlanır). Duygu düzenleme; 1, 3, 7, 15, 21, 23, 16 (tersten puanlanır), 18 (tersten puanlanır). Alt ölçeklerin ortalama puanları hesaplanır. Batum ve Yağmurlu tarafından Tükçeye uyarlama çalışmasında iç tutarlılık katsayıları Duygu Düzenleme 
alt ölçeği .73, Değişkenlik/Olumsuzluk alt ölçeği için ise .75 olarak bulunmuştur (Batum ve Yağmurlu, 2007).

\section{Çocuklar için Kısa Mizaç Ölçeği (ÇKMÖ)}

ÇKMÖ Prior, Sanson ve Oberklaid (1989) tarafından geliştirilmiştir. Yağmurlu ve Sanson (2009) tarafından çeviri-geri çeviri yolu ile Türkçe'ye uyarlanmıştır. Çocuklar için Kısa Mizaç Ölçeği 30 maddeden oluşur. Puanlaması 1 (Hemen Hiç) ile 6 (Hemen Her Zaman) arasındadır. Sıcakkanlılık/Utangaçlık, Sebatkarlık, Ritmiklik ve Tepkisellik olmak üzere 4 alt ölçekten oluşur (Yağmurlu ve Altan, 2010). Puanlama alt ölçekteki tüm maddelerin ortalaması alınarak hesaplanır.İç tutarlılık katsayısı; Sıcakkanlılık/Utangaçlık .80, Tepkisellik için .77, Sebatkarlık için .76 ve Ritmiklik için .48 olarak bulunmuştur (Yağmurlu ve Sanson, 2009).

\section{Ebeveyn Tutum Ölçeği (ETÖ)}

Ebeveyn Tutum Ölçeği (ETÖ), Karabulut Demir ve Şendil (2008) tarafından ebeveynlerin 2-6 yaş arasındaki çocuklarına olan davranışlarını ölçmek amacıyla geliştirilmiştir. Ebeveynlere uygulanabilen ölçek, 4 alt boyuttan ve 46 maddeden oluşmaktadır. Alt boyutlar şunlardır: Demokratik Tutum Boyutu (17 madde), Otoriter Tutum Boyutu (11 madde), Aşırı Koruyucu Tutum Boyutu (9 madde), ve İzin Verici Tutum Boyutu (9 madde). Ölçek 5'li Likert tipindedir."Her zaman böyledir" 5 puan; "Çoğunlukla böyledir" 4 puan; "Bazen böyledir" 3 puan; "Nadiren böyledir" 2 puan ve "Hiçbir zaman böyle değildir" 1 puan almaktadır. Böylece yanıtlayan anne-babaların, bahsi geçen davranışı ne sıklıkta yaptıklarını ifade etmeleri sağlanmıştır. Her boyuttan alınan puanlar ayrı ayrı hesaplanarak her boyut için bir puan elde edilmektedir. Bir boyuttan yüksek puan almak, o boyutun temsil ettiği davranış şeklini benimsemek anlamina gelmektedir.

Geçerlik ve güvenirlik çalışması sonucunda ETÖ boyutlarının Cronbach alfa güvenirlik katsayıları Demokratik Tutum Boyutu için .83, Otoriter Tutum Boyutu için .76, Aşırı Koruyucu Tutum Boyutu için .75 ve izin verici boyutu için .74 olarak bulunmuştur (Karabulut ve Şendil, 2008).

\section{Verilerin Toplanması}

Verilerin toplanması için 26.10.2016 tarih ve toplantı no:3 olan etik kurul izni alınmıştır. Adana Valilik Oluru tarafindan verilen izin 24.03.2017 tarihinde verilen uygulama izni ile veri toplama süreci başlatılmıştır. Çocukların ailelerine öğretmenler aracılığıyla Genel Bilgi Formu, Çocuklar için Kısa Mizaç Ölçeği (ÇKMÖ) ve Ebeveyn Tutum Ölçeği (ETÖ) gönderilerek doldurmaları istenmiştir. Öğretmenlerden ise her öğrencisi için ayrı ayrı Duygu Düzenleme Ölçeğini (DDÖ) doldurması istenmiştir. Ölçeklerin ebeveynlere dağıtılıp, doldurulup gelmesi için her öğretmene 5 gün süre verilmiştir. Araştırmacı ölçekleri dağıtmak için ve öğretmenlerden doldurulmuş ölçekleri toplamak için en az iki kez okula gitmiştir. 400 Ölçeğin geri dönüşü olmuştur.

\section{Verilerin Analizi}

Duygu Düzenleme Ölçeği (DDÖ), Ebeveyn Tutum Ölçeği (ETÖ) ve Çocuklar için Kısa Mizaç Ölçeği (ÇKMÖ) arasındaki ilişki incelenirken değişkenlerin normal dağılımdan gelip gelmediğini öğrenmek amacıyla Kolmogorov Smirnov Z testi yapılmıştır. Test sonucunda değişkenlerin normal dağılımdan gelmediği sonucuna ulaşılmıştır. Çocukların DDÖ ve ÇKMÖ arasında ve çocukların DDÖ ile ETÖ arasında anlamlı bir ilişki olup olmadığı Spearman Brown Korelasyon katsayısı ile hesaplanmıştır. 


\section{BULGULAR VE TARTIŞMA}

Çocukların duygu düzenleme becerileri ve ebeveyn tutumları arasında anlamlı bir ilişki olup olmadığı Spearman Brown korelasyon katsayısı sonuçları Tablo 2'de gösterilmiştir.

Tablo 1. DDÖ ve ETÖ Puanlarının Spearman Brown Korelasyon Katsayısı Sonuçları

\begin{tabular}{llcc}
\hline ETÖ Alt Boyutlar & & Değişkenlik/Olumsuzluk & Duygu Düzenleme \\
\hline Demokratik Tutum & $\mathrm{r}$ &,- 033 &, $114^{*}$ \\
& $\mathrm{p}$ &, 504 &, 023 \\
\hline Otoriter Tutum & $\mathrm{r}$ &, $169^{*}$ &,- 001 \\
& $\mathrm{p}$ &, 001 &, 991 \\
\hline \multirow{2}{*}{ Așırı Koruyucu Tutum } & $\mathrm{r}$ &, 062 &,- 020 \\
& $\mathrm{p}$ &, 214 &, 684 \\
\hline İzin Verici Tutum & $\mathrm{r}$ &, 052 &, 000 \\
& $\mathrm{p}$ &, 298 &, 999 \\
\hline
\end{tabular}

$* \mathrm{p}<0.05$

Çocukların DDÖ duygu düzenleme alt boyut puanları ile ETÖ demokratik tutum puanları arasında pozitif yönlü düşük düzeyde anlamlı bir ilişki bulunmuştur $(\mathrm{r}=0.114, \mathrm{p}<0.05)$. Buna göre çocukların Duygu Düzenleme puanları arttıkça Demokratik Tutum puanları da artmaktadır. Çocukların DDÖ Değişkenlik/Olumsuzluk alt boyut puanı ile ETÖ Otoriter Tutum alt boyut puanları arasında pozitif yönlü düşük düzeyde anlamlı bir ilişki bulunmuştur $(\mathrm{r}=0.169$, $\mathrm{p}<0.05)$. Buna göre, ebeveynlerin Otoriter Tutumu arttıkça çocukların duygu düzenlemedeki Değişkenlik/Olumsuzluk durumlarının da arttığı söylenebilir ( $\mathrm{p}>0.05)$.

Araştırmada ilk olarak çocukların duygu düzenleme becerileri ile ebeveyn tutumları arasındaki ilişki incelenmiştir. Demokratik ebeveyn tutumu ile çocukların duygu düzenleme becerisi arasında pozitif yönlü düşük düzeyde anlamlı bir ilişki bulunmuştur. Demokratik ebeveyn tutumu ile yetişen çocuk özgüveni yüksek, yaratıcı, toplumsal birey haline gelir. Kendi kontrolünü sağlayabilir ve sağlıklı kişilik geliştirir (Yavuzer, 2016). Yaman'ın 2018 yılında yaptığı çalışmada araştırmaya okul öncesi eğitim kurumlarına devam eden çocukların ebeveynleri ve öğretmenleri katılmıştır. Rastgele 102 çocuğun ebeveyni ve öğretmeni seçilmiştir. İstanbul'da yürütülen bu çalışma sonuçlarına göre de demokratik ebeveyn tutumu ile duygu düzenleme becerisi arasında, duygu düzenleme yetersizliği ile otoriter ebeveyn tutumu arasında pozitif ilişki olduğu tespit edilmiştir. Bu çalışmalar, demokratik ebeveyn tutumlarının duygu düzenleme becerisinin üzerinde olumlu etkisi olduğunu düşündürebilir. Mathis ve Bierman'ın (2015) araştırmalarında da ebeveyn tutumları ile çocukların duygu düzenleme becerileri arasında pozitif yönlü ilişki olduğu belirlenmiştir. Jabeen ve Anis-ulHaque'nin (2013) ergenler üzerinde yaptığı diğer bir araştırmada da, ebeveynin demokratik tutumu ile çocuğun duygu düzenleme becerisi arasında pozitif yönlü ilişki bulunmuştur. $\mathrm{Bu}$ araştırmaların sonuçları bulgularımızı destekler niteliktedir. Bu çalışmalar, demokratik ebeveyn tutumlarının duygu düzenleme becerisinin üzerinde olumlu etkisi olduğunu gösterebilir. $\mathrm{Bu}$ bulguların aksine Eke'nin (2017) çalışmasında okul öncesi dönemde demokratik ebeveyn tutumu ile çocukların öz düzenleme becerileri arasında anlamlı ilişki görülmemiştir.

$\mathrm{Bu}$ araştırmaya göre, otoriter ebeveyn tutumu ile duygu düzenlemenin değişkenlik/olumsuzluk alt boyutu arasında düşük düzey pozitif ilişki belirlenmiştir. Otoriter ebeveyn tutumu ile yetişen çocuklar çekingen, özsaygısı düşük ve saldırgan bireyler haline gelir (Yörükoğlu, 2015). Bu çalışma otoriter ebeveyn tutumunun çocuğun duygu düzenleme becerisini olumsuz yönde etkilediğini gösterebilir. Eisenberg ve arkadaşlarına göre (2010) otoriter ebeveyn tutumu çocukların duygu düzenleme becerilerini negatif yönde etkiler. Yaman'ın (2018) yaptığı araştırma sonucu çalışmanın bu bulgusunu desteklemektedir. Ebeveynlerin çocuğu birey olarak görmemesi, çocuğun duygularını bastırması ya da yok sayması çocukların duygularını 
düzenlemesini engeller (Sarıtaş-Atalar ve Altan-Altay, 2018). Çocukların duygu düzenleme becerileri ve mizaçları arasında anlamlı bir ilişki olup olmadığı Spearman Brown korelasyon katsayısı sonuçları Tablo 2'te gösterilmiştir.

Tablo 3. DDÖ ve ÇKMÖ Puanlarının Spearman Brown Korelasyon Katsayısı Sonuçları

\begin{tabular}{llll}
\hline $\begin{array}{l}\text { ÇKMÖ } \\
\text { Alt Boyutlar }\end{array}$ & & $\begin{array}{l}\text { Değişkenlik/ } \\
\text { Olumsuzluk }\end{array}$ & Duygu Düzenleme \\
\hline Sıcakkanlılık-utangaçlık & $\mathrm{r}$ &,- 062 &, 082 \\
\hline & $\mathrm{p}$ &, 214 &, 101 \\
\hline Sebatkarlık & $\mathrm{r}$ &,$- 121^{*}$ &, 076 \\
\hline & $\mathrm{p}$ &, 015 &, 129 \\
\hline Ritmiklik & $\mathrm{r}$ &, 040 &,- 070 \\
Tepkisellik & $\mathrm{p}$ &, 426 &, 163 \\
\hline & $\mathrm{r}$ &, $137^{*}$ &,- 077 \\
\hline
\end{tabular}

${ }^{*} \mathrm{p}<0.05$

Tablo 3'e göre, DDÖ Değişkenlik/Olumsuzluk alt boyut puanları ile ÇKMÖ Sebatkarlık alt boyutu arasında -0.121 olan negatif yönlü düşük düzeyde anlamlı bir ilişki bulunmuştur $(\mathrm{r}=$ $0.121, \mathrm{p}<0.05)$. Buna göre, çocukların duygu düzenlemedeki Değişkenlik/Olumsuzluk puanları arttıkça çocuklarda mizaç özelliklerinden biri olan sebatkarlık alt boyutundaki puanları azalmaktadır.

Çocukların DDÖ Değişkenlik/Olumsuzluk alt boyutu ile ÇKMÖ Tepkisellik alt boyutu arasında pozitif yönlü düşük düzeyde anlamlı bir iliş̧i bulunmuştur $(\mathrm{r}=0.137, \mathrm{p}<0.05)$. Buna göre, çocukların duygu düzenlemedeki Değişkenlik/Olumsuzluk durumu arttıkça çocuklarda tepkisellik mizaç alt boyutu da artmaktadır. Diğer ölçümler arasında anlamlı birer ilişki bulunamamıştır ( $\mathrm{p}>0.05)$.

Duygu düzenleme becerileri ile mizaç arasında düşük düzey anlamlı bir ilişki bulunmuștur. Yapılan araştırmada, duygu düzenlemenin değişkenlik/olumsuzluk boyutu ile sebatkarlık mizaç özelliği arasında negatif, duygu düzenlemenin değişkenlik/olumsuzluk boyutu ile tepkisellik mizaç özelliği arasında pozitif yönlü düşük düzey anlamlı ilişki olduğu sonucuna ulaşılmıştır. $\mathrm{Bu}$ araştırma sonucuna göre duygu düzenleme yetersizliği yüksek olan çocukların mizaç olarak daha tepkisel ancak daha az sebatkar olduğu sonucuna ulaşılır. Akbaba 2017 yılında yürüttüğü araştırmasında örneklemi 551 (5-6 yaş) çocuğun öğretmeni ve çocuğun annesi oluşturmaktadır. $\mathrm{Bu}$ araştırmanın sonuçlarına göre, tepkisellik mizaç özelliği ile duygu düzenleme yetersizliği arasında pozitif yönde ve orta düzeyde bir ilişki saptanmıştır. Aynı çalışmada sebatkarlık mizaç özelliği ile duygu düzenleme yetersizliği arasında negatif yönde ve orta düzeyde bir ilişki bulunmuştur. Bu sonuçlar araştırma bulgusunu destekler niteliktedir. Yine Altan'ın (2006) yapmış olduğu anne sosyalizasyonu ile çocuğun mizaç özelliklerinin çocuğun duygu düzenleme becerisine olan etkisini incelediği çalışmada benzer bulgular ortaya çıkmıştır. $\mathrm{Bu}$ sonuçlara göre; annelerin olumlu ebeveyn davranışları, tepkisel mizaç ve olumlu ebeveyn davranışları ile sıcakkanlı mizaç arasındaki etkileşim, duygu düzenleme becerisini etkilemektedir. Duygu düzenleme ve mizaç özellikleri arasında ilişki olduğu belirlenmiştir. Çocuğun duygu düzenleme becerisi çocuğun mizacına göre değişiklik gösterir. Literatür incelendiğinde duygu düzenleme ve mizaç arasında ilişki olmadığına dair bir araştırmaya rastlanmamıştır. Bu bulgular ışığında çocuğun mizacının duygu düzenleme becerisini anlamlı derecede etkilediği söylenebilir 


\section{SONUÇ VE ÖNERILER}

Çocukların duygu düzenleme becerileri ile mizaç ve ebeveyn tutumları arasındaki ilişkinin incelendiği bu çalışma sonucunda, demokratik ebeveyn tutumu ile duygu düzenleme becerisinde yeterli olma arasında pozitif yönlü düşük düzeyde, otoriter ebeveyn tutumu ile duygu düzenleme becerisinin değişken/olumsuz olma alt boyutu arasında ise pozitif yönlü düşük düzeyde anlamlı bir ilişki belirlenmiştir. Çocukların duygu düzenleme becerileri ile mizaç özellikleri arasındaki ilişkiye yönelik olarak; duygu düzenleme becerisi değişken/olumsuz olma ile sebatkarlık mizaç özelliği arasında negatif, duygu düzenleme becerisi değişken/olumsuz olma ile tepkisellik mizaç özelliği arasında pozitif yönlü düşük düzey anlamlı ilişki olduğu sonucuna ulaşılmıştır. Duygu düzenleme becerisinin gelişimi ebeveyn tutumlarından etkilenir. Bu sebeple ebeveyn olan ve ebeveyn adayı olan herkese sağlıklı çocuk yetiştirmeye yönelik aile eğitimleri verilmelidir. Ebeveynlerin çocuklarına karşı kabul edici olmaları, gerekli ilgi ve yakınlığı göstermeleri bununla birlikte çocuklarının davranışlarına yönelik sınır koyabilmedeki yeterlilikleri sağlıklı bir ruhsal gelişim için ön koşuldur. Her çocuk duygularını farklı şekillerde ifade eder. Çocukların mizacına uygun yaklaşımlar sergilenmesi çocuğun duygu düzenleme becerilerinin gelişmesinde oldukça önemlidir. Her ebeveyn çocuğunun duygusal ipuçlarına dikkat etmeli ve çocuklarının nasıl hissettiğini anlamalarına yardımcı olmalıdır. Çocuğun çeşitli duygu durumlarını (öfke, hayal kırıklığı, mutluluk, korku, heyecan vd.) nasıl ifade ettiğine ilişkin ipuçlarını tanımak ve anlamak duygu düzenleme becerilerin gelişmesine yardımcı olacaktır. Ayrıca duygu düzenleme becerilerini öğretmenin en etkili yolu doğru ve güçlü modeller sunmaktır. Çocuk evde anne ve babasını rol model alır. Bu nedenle ebeveynler gün boyunca duygularını düzenlemenin yollarını kasıtlı olarak göstermek için zaman ayırabilir, ne yaptıklarını ve nedenlerini açıklayabilir (örneğin, '.....olduğunda çok öfkelendim bu yüzden kendimi sakinleştirmek için birkaç derin nefes aldım). Çocukların en çok vakit geçirdiği yer aile dışında okuldur. Öğretmenler ve öğretmen adayları da duygu düzenleme becerileri hakkında bilgi sahibi olmalı ve öğretmenler planlarında çocuklarda bu beceriyi geliştirici zengin deneyimler sağlayan etkinlikler düzenlemelidir. Ayrıca sınıf ortamında öğretmenin öğrencisinin mizaç özelliğine tanıması ve bu mizaca uygun davranması da çok önemlidir. Bunun için öğretmen ve öğretmen adaylarının da hizmet öncesi ve hizmet içi eğitimlerinde mizacın belirlenmesi ve mizaca uygun eğitimden ortamlarının düzenlenmesi ve çocukla iletişim konusunda yapabileceklerine ilişkin bilgilendirilmesi gerekmektedir. Öğretmen bu konuda daha donanımlı olursa, çocuğu daha kolay keşfedebilir, daha aktif hale getirir ve tüm bunları gerçekleştirirken çocuğun özsaygısı her zaman yüksek olur. Ebeveynlerin ve öğretmenlerin çocukların duygusal deneyimlerini etkili bir şekilde yönetmeyi öğrenmelerine yardımcı olmaları çocukların sosyal ve akademik alanlardaki becerilerinin gelişimine de katkı sağlayacaktır. Duygu düzenleme becerisine sahip olmanın öneminin yeterince anlaşılabilmesi ve bu becerinin nasıl daha iyi desteklenebileceğinin fark edilmesi için çok sayıda araştırmaya ihtiyaç duyulmaktadır. Bu nedenle benzer araştırmalar farklı örneklem gruplarında tekrarlanabilir. Duygu düzenleme becerilerinde kültüründe önemli bir faktör olduğu düşünüldügüünde kültürün etkisini belirlemek için kültürler arası karşılaştırmalı araştırmalar yapılabilir. Yaşa göre duygu düzenleme becerilerindeki değişimleri belirlemek için boylamsal çalışmalar yapılabilir. Duygu düzenleme konusunda ebeveynlerin sundukları rol modelin etkisi dikkate alındığında ebeveynlerin duygu düzenleme becerileri ve çocukların duygu düzenleme becerileri arasındaki ilişkiyi belirlemeye yönelik ilişkisel çalışmalara da ihtiyaç duyulmaktadır. Dikkat Eksikliği Hiperaktivite Bozukluğu ve öğrenme güçlügü gibi yetersizliği olan çocukların duygu düzenleme becerileri ve normal gelişim gösteren çocukların duygu düzenleme becerilerini inceleyen karşılaştırmalı çalışmalar da yapılabilir. Ayrıca aile birlikte yaşayan ve ailesiyle birlikte yaşamayan korunmaya muhtaç çocukların duygu düzenleme becerilerinin karşılaştırıldığı çalışmalar planlanabilir. 


\section{KAYNAKÇA}

Akbaba, G. (2017). Beş Altı Yaş Çocuklarının Duygu Düzenlenmesinde Çocuk Mizacıyla Anne Davranışları Arasındaki Etkileşimin Incelenmesi. (Yüksek lisans tezi). İstanbul Üniversitesi/ Eğitim Bilimleri Enstitüsü, İstanbul.

Aldao, A. (2013). The future of emotion regulation research: Capturing context. Perspectives on Psychological Science, 8(2), 155-172.

Altan, Ö. (2006). The Effects Of Maternal Socialization and Temperament on Children's Emotion Regulation. (Yüksek lisans tezi). Koç Üniversitesi, Sosyal Bilimler Enstitüsü, İstanbul.

Arı, M., \& Yaban, H. (2016). Okul öncesi dönemdeki çocukların sosyal davranışları: Mizaç ve duygu düzenlemenin rolü. Hacettepe Üniversitesi Ĕ̈itim Fakültesi Dergisi, 31(1), 125141.

Batum, P., \& Yagmurlu, B. (2007). What counts in externalizing behaviors? The contributions of emotion and behavior regulation. Current Psychology: Developmental Learning Personality Social, 25(4), 272-294.

Berk L. E. (2013). Child Development. Çocuk Gelişimi. $1^{\text {the }}$, Çeviren: Dönmez A, İmge Kitabevi, Ankara

Berk L. E. (2013). Infants and Children Prenatal Through Middle Chilhood. Doğum Öncesinden Orta Çocukluğa Bebekler ve Çocuklar. N. Işıkoğlu-Erdoğan (Çev.) Ankara: Nobel Akademik Yayıncılık (7.bask1)

Bozkurt Yükçü, Ş. (2017). Bağımsız Anaokullarına Devam Eden Çocukların Duygu Düzenleme ve Sosyal Problem Çözme Becerileri ile Ebeveynlerinin Duygusal Okuryazarlık Düzeyleri Arasındaki Illişkinin İncelenmesi. (Yayımlanmamış yüksek lisans tezi). Hacettepe Üniversitesi/ Sağlık Bilimleri Enstitüsü, Ankara.

Büyüköztürk, Ş., Kılıç, E., Akgün, Ö.E., Karadeniz, Ş., Demirel, F. (2016). Bilimsel araştırma yöntemleri. Ankara: Pegem Akademi

Brownell, C. A., \& Kopp, C. B. (2007). Transitions in toddler socioemotional development: behavior, understanding, relationships. In C. A. Brownell, C. B. Kopp (Eds.), Socioemotional development in the toddler years (pp. 19-65). New York: The Guilford Press

Calkins, S. D., \& Fox, N. A. (2002). Self-regulatory processes in early personality development: A multilevel approach to the study of childhood social withdrawal and aggression. Development and psychopathology, 14(3), 477-498.

Calkins, S. D., \& Hill, A. (2007). Caregiver influences on emerging emotion regulation. Handbook of emotion regulation, 229-248.

Campos, J. J., Campos, R. G., \& Barrett, K. C. (1989). Emergent themes in the study of emotional development and emotion regulation. Developmental psychology, 25(3), 394.

Cole, P. M., Martin, S. E., \& Dennis, T. A. (2004). Emotion regulation as a scientific construct: Methodological challenges and directions for child development research. Child development, 75(2), 317-333.

Demirkapı-Şahin, E. (2013). Çocukluk Çă̆ı Travmalarının Duygu Düzenleme ve Kimlik Gelişimine Etkisi ve Bunların Psikopatolojiler ile İlişkisi. (Yüksek lisans tezi). Adnan Menderes Üniversitesi/ Sağlık Bilimleri Enstitüsü, Aydın.

Dodge, K. A. ve Garber, J. (1991). Domains of Emotion Regulation. In: The Development of Emotion Regulation and Dysregulaton. Eds: Dodge K.A., Garber J., 1th ed, Cambridge University Press, New York, p.3-11.

Eisenberg, N., Spinrad, T. L., \& Eggum, N. D. (2010). Emotion-related self-regulation and its relation to children's maladjustment. Annual review of clinical psychology, 6, 495-525.

Eke K. (2017). Examining The Relationship Between Preschool Children's Self-Regulation Skılls and Parental Attıtudes. International Congress Of Eurasian Social Sciences. 8(28). 
Ersan, C. (2017). Okul Öncesi Dönem Çocukların Saldırganlık Düzeylerinin Duygu İfade Eeme ve Duygu Düzenleme Açısında Incelenmesi. (Doktora tezi). Pamukkale Üniversitesi Eğitim Bilimleri Enstitüsü, Denizli.

Essau, C.A., LeBlanc, S.S., Ollendick, T.H. (Eds.), (2017). Emotion Regulation and Psychopathology in Children and Adolescents. $1^{\text {th }}$ ed, Oxford University Press, United Kingdom

Fox, N. A., \& Calkins, S. D. (2003). The development of self-control of emotion: Intrinsic and extrinsic influences. Motivation and emotion, 27(1), 7-26

Fraenkel JR, Wallen NE, Hyun HH. (2012). How to design and evaluate research in education (8th ed.). New York: McGraw-Hill.

Firoozi, M., Besharat, M. A., \& Boogar, E. R. (2013). Emotional regulation and adjustment to childhood cancer: role of the biological, psychological and social regulators on pediatric oncology adjustment. Iranian journal of cancer prevention, 6(2), 65.

Firoozi, M., Besharat, M. A., \& Tehrani, S. P. (2011). Cognitive Emotion Regulation in Children with Acute Lymphoblastic Leukemia. Iranian Journal of cancer prevention, 4(4), 183.

Goldstein, S. (2015). Gender Differences in Children's Emotion Regulation from Preschool to School Age (Doctoral dissertation).

Gross, J. J. (1998). The emerging field of emotion regulation: an integrative review. Review of general psychology, 2(3), 271

Gross, J. J. (Ed.). (2007). Handbook of emotion regulation. New York: Guilford.

Gross, J. J. ve Thompson, R. A. (2007). Emotion regulation: Conceptual foundations. In J. J. Gross (Ed.), Handbook of emotion regulation (pp. 3-24). New York: Guilford Press.

Jabeen, F., ve Anis-ul-Haque, M. (2013). Parenting styles as predictors of emotion regulation among adolescents. Pakistan Journal of Psychological Research, 28(1), 85-105.

Karabulut-Demir E. ve Şendil G. (2008). Ebeveyn tutum ölçeği. Türk Psikoloji Yazıları, Haziran 2008, 11 (21), 15-25.

Kayhan Aktürk, Ş. (2015). Okul Öncesi Dönem Çocuklarında Duygu Düzenleme Becerileri ile Akran İlişkilerinin İncelenmesi. Yüksek lisans tezi. İstanbul Üniversitesi Eğitim Bilimleri Enstitüsü, İstanbul.

Kelly, K., Slade, A., \& Grienenberger, J. F. (2005). Maternal reflective functioning, motherinfant affective communication, and infant attachment: Exploring the link between mental states and observed caregiving behavior in the intergenerational transmission of attachment. Attachment \& human development, 7(3), 299-311.

Kopp, C. B. (1982). Antecedents of self-regulation: A developmental perspective. Developmental Psychology, 18(2), 199-214.

LaFreniere, P. (2013). Children's play as a context for managing physiological arousal and learning emotion regulation. Psihologijske teme, 22(2), 183-204.

Mathis, E. T., ve Bierman, K. L. (2015). Dimensions of parenting associated with child prekindergarten emotion regulation and attention control in low-income families. Social Development, 24(3), 601-620.

Ochsner, K. N., \& Gross, J. J. (2005). The cognitive control of emotion. Trends in cognitive sciences, 9(5), 242-249.

Prior, M. R., Sanson, A. V., \& Oberklaid, F. (1989). The Australian temperament project.

Rieder, C., \& Cicchetti, D. (1989). Organizational perspective on cognitive control functioning and cognitive-affective balance in maltreated children. Developmental psychology, 25(3), 382.

Rothbart, M. K. (2004). Temperament and the pursuit of an integrated developmental psychology. Merrill-Palmer Quarterly (1982-), 492-505. 
Rothbart, M. K., \& Bates, J. E. (2006). Temperament. In Damon W., Lerner R., Eisenberg N. (Eds.), Handbook of Child Psychology: Vol. 3 (6th ed., pp. 99-166). NY: Wiley

Rothbart, M. K., Ziaie, H. and O'boyle, C. G. (1992). Self-regulation and emotion in infancy. New directions for child and adolescent development, (55), 7-23.

San-Bayhan P. ve Artan İ. (2011). Çocuk Gelişimi ve Eğitimi. İstanbul: Morpa Yayınları.

Santrock J W. (2015). Life Span Development. Yaşam Boyu Gelişim. 13thed, Çeviren: Galip Yüksel. Ankara: Nobel Akademik Yayıncılık.

Sarıtaş Atalar, D. ve Altan-Atalay, A. (2018). Ergenlik döneminde duygu düzenleme ve ruh sağlı̆̆l: ana-babanın ve mizacın rolü (Ed.: T. Bildik) Ergenlik Dönemi ve Ruhsal Bozukluklar. Ankara: Türkiye Klinikleri, 84-9.

Seçer, Z. (2017). Sosyal olarak yetkin okul öncesi çocukların duygu düzenlemeleri İle annelerinin duygu sosyalleştirme davranışları arasındaki ilişkiler. Kastamonu Üniversitesi Kastamonu Ĕ̈itim Dergisi, 25(4), 1435-1452.

Shahba, S., Alvani, S., Zahedi, S., \& Memarzadeh, G. (2014). An investigation on the effect of cognitive emotion regulation strategies on job satisfaction. Management Science Letters, 4(6), 1315-1324.

Shields, A., \& Cicchetti, D. (1997). Emotion regulation among school-age children: the development and validation of a new criterion Q-sort scale. Developmental psychology, 33(6), 906.

Sille, A. (2016). Annenin Duygusal Sosyalizasyonu ile 48-72 Aylık Çocukların Duygu Düzenleme Becerisi Arasındaki İlişki. (Yüksek Lisans Tezi). Maltepe Üniversitesi Sosyal Bilimler Enstitüsü, İstanbul.

Southam-Gerow, M A. (2014). Emotion regulation in chıldren and adolescents. Çocuklarda ve ergenlerde duygusal düzenleme. $1^{\text {th }}$ ed, Çeviren : Şahin M ve Artıran M. Ankara: Nobel Akademik Yayıncilık.

Stifter, C. A., Dollar, J. M., \& Cipriano, E. A. (2011). Temperament and emotion regulation: the role of autonomic nervous system reactivity. Developmental psychobiology, 53(3), 266-279.

Thompson, R. A. (1994). Emotion regulation: A theme in search of definition. N. Fox (Der.), The development of emotion regulation: Biological and behavioral considerations, Monographs of the Society for Research in Child Development, 59 (2-3, seri no. 240), 25 52.

Thompson, R. A., \& Calkins, S. D. (1996). The double-edged sword: Emotional regulation for children at risk. Development and Psychopathology, 8(1), 163-182.

Uğur Ulusoy, R. Gözün Kahraman, Ö. (2019). Okul Öncesi Dönem Çocukları için Duygu Düzenleme Becerilerine Yönelik Hazırlanan Aile Katılımlı Eğitim Programının Etkililiğinin İncelenmesi, Uluslararası Aile Çocuk ve Eğitim Dergisi, 17 (4).

Yagmurlu, B.ve Sanson, A. (2009). Parenting and temperament as predictors of prosocial behaviour in Australian and Turkish Australian children. Australian Journal of Psychology, 61(2), 77-88

Yagmurlu, B., \& Altan, O. (2010). Maternal socialization and child temperament as predictors of emotion regulation in Turkish preschoolers. Infant and Child Development: An International Journal of Research and Practice, 19(3), 275-296.

Yaman B. (2018). Ebeveyn tutumlarının çocukların mizaç özellikleri ve duygu düzenleme becerileri üzerindeki rolü (Yüksek Lisans Tezi). Işık Üniversitesi Sosyal Bilimler Enstitüsü, İstanbul.

Yavuzer H. (2016). Ana-baba ve çocuk. 26.Bask1. Ankara: Remzi Kitabevi.

Yörükoğlu A.( 2015). Çocuk ruh Sağlı̆̆ı. 36. Basım. İstanbul: Özgür Yayın Dağıtım 